\title{
FACTORS THAT INFLUENCE E-LOYALTY OF INTERNET BANKING USERS
}

\author{
Ameen M Al-Agaga \\ Universiti Teknologi Malaysia \\ Johor Bahru, 81310 Johor, Malaysia \\ ameen_mahdi@hotmail.com \\ Khalil Md Nor \\ Universiti Teknologi Malaysia \\ Johor Bahru, 81310 Johor, Malaysia \\ m-khalil@utm.my
}

\begin{abstract}
The objective of this study was to examine factors that influence customer e-loyalty. In this respect, we identified three factors that may influence customer e-loyalty, namely trust, customer satisfaction, and sense of belonging. We used Internet banking as the target technology and college students as subjects for this study. One hundred and nineteen questionnaires were used for the data analysis and multiple regression analyses were conducted to analyze the data. Trust, customer satisfaction, and sense of belonging were found to have a significant impact on customer e-loyalty in Internet banking.
\end{abstract}

Keywords: Customer E-loyalty, Trust, Customer Satisfaction, Sense of Belonging

\section{INTRODUCTION}

The revolution in information technology has a direct influence on the way business is conducted. In the banking industry, one of the most notable and momentary developments has been the introduction of Internet banking. Internet banking offers customers the flexibility of 24-hour access to banking services without the need to visit the bank for most services and transactions ${ }^{1}$.

The banking sector has witnessed major developments over the past three decades, especially in the automation of banking services and the use 
of banking technologies to achieve cost goals and better serve their customers $^{2}$. Pikkarainen et al. ${ }^{3}$ pointed out that Internet banking is one of the cheapest channels for banking products. According to Reichheld et al. ${ }^{4}$ and Reichheld and Schefter ${ }^{5}$, the high costs associated with winning new e-customers, which is essential for banks to maintain their current customers and make them loyal. Meanwhile, customer loyalty in the Internet banking era has become a critical issue because it has a constructive and positive influence on banks' long-term profitability ${ }^{6}$. Therefore, there is a need to determine what influences customer e-loyalty. As such, the main purpose of this study was to investigate whether trust, customer satisfaction, and sense of belonging influence customer e-loyalty in Internet banking.

\section{LITERATURE REVIEW}

Customer e-loyalty is a new concept and is considered to be a branch of concept of loyalty, which is implemented in the e-commerce domain. This was introduced first by Reichheld and Schefter ${ }^{5}$. Additionally, Sohn and Lee ${ }^{7}$ defined e-loyalty as "customers' behaviour to visit and revisit the specific website and make transactions comfortably." E-loyalty was also defined as "a customer's favorable attitude toward the e-retailer that results in repeat buying behavior" by Srinivasan et al. ${ }^{8}$. The high competitiveness in the online retail environment has resulted in enhancing e-loyalty, which has become a key for the survival of online retailers, as competition is just 'a mouse click away, ${ }^{5}$.

Trust has been indicated as one of the major determinants of e-loyalty in most retailing environments ${ }^{8,9}$. Lewis and Soureli ${ }^{10}$ defined trust as "a feeling of security, based primarily on the belief that one party's behavior is guided by favorable intentions towards the best interest of the other." Moorman et al. ${ }^{11}$ define trust as "the willingness to rely on an exchange partner in whom one has confidence." As such, trust in e-retailing is the belief or expectation that the retailer can keep promises and can be depended on ${ }^{12}$. In the context of online banking, trust assists in removing perceptions that are related to risk and insecurity among online customers when they are engaged in online financial activities. To gain and sustain a competitive advantage, online providers need to create trust, which later enhances e-loyalty ${ }^{5}$. Prior studies ${ }^{13,14}$ have indicated that trust is considered to be an important aspect to developing long-term customer relations. Floh and Treiblmaier ${ }^{15}$ showed that the relationship between trust and customer loyalty is directly proportional.

Another driver of e-loyalty is customer satisfaction ${ }^{16,17}$. Customer satisfaction is defined as "an overall evaluation based on the total purchase 
and consumption experience focused on the perceived product or service performance compared with pre-purchase expectations over time" ${ }^{\text {"18 }}$. Many researchers ${ }^{19,20,21}$ have examined the significant role of satisfaction in forming customer loyalty and have shown a positive effect of satisfaction on the continued activities in online transactions. For example Ribbink, et al. ${ }^{6}$ found that when customers are satisfied with a specific online retailer, they are willing to repeat purchases with that retailer. Moreover, other researchers have found a direct effect of satisfaction on customer e-loyalty ${ }^{22}$, 23.

Several studies ${ }^{5,24,25,26}$ have also recognized and acknowledged sense of belonging and loyalty as the prime factors, which can determine the success of the online customer relationship. Hagel and Armstrong ${ }^{27}$ suggested that the intention to buy is influenced by a sense of belonging. Roberts ${ }^{28}$ argued that individuals with a higher sense of belonging put more time and effort into their online participation. Consequently, a sense of belonging influences a customer's repeat purchasing behaviors ${ }^{29}$. In a study conducted by Morgan and Hunt ${ }^{26}$, sense of belonging influenced loyalty to an online relationship. Similarly, Moorman et al. ${ }^{11}$ found that sense of belonging positively affected customer loyalty. In an online business, Kim et al. ${ }^{30}$ suggested that sense of belonging was regarded an essential feature for winning customer loyalty. Specifically, sense of belonging allows the customer to be part of the seller, thus, creates a lasting relationship with the seller $^{26,31}$. In this study, we defined sense of belonging as the experiences of customer involvement in a bank via Internet banking so that the customer feels himself as an integral part of the bank.

As mentioned previously, we empirically examined the three factors that may influence e-loyalty namely: trust, customer satisfaction, and sense of belonging. Three hypotheses of this study included:

Hypothesis 1: Trust has a positive effect on customer e-loyalty in Internet banking.

Hypothesis 2: Customer satisfaction has a positive effect on customer e-loyalty in Internet banking.

Hypothesis 3: Sense of belonging has a positive effect on customer e-loyalty in Internet banking. 


\section{METHODOLOGY}

Students from a public university in Malaysia participated in this study. We used a questionnaire as the method to collect data and all items intended to measure the variables in this study (i.e., trust, customer satisfaction, sense of belonging and customer e-loyalty) were adopted from previously validated instruments ${ }^{32,33,34}$. We performed a factor analysis to assess the validity of the instrument and used multiple regressions to test the model.

\section{ANALYSIS}

We collected a total of 129 questionnaires out of 130 questionnaires distributed, which indicates a $99.2 \%$ rate of return. Of the 129 returned questionnaires, 10 were incomplete questionnaires and were discarded. Having dropped cases of incomplete questionnaires, we used a total of 119 questionnaires for the data analysis, which indicates a response rate of $91.15 \%$. About $57 \%$ of the respondents were female and $43 \%$ were male. The mean age of the respondent was about 25 years old. Among the respondents, $66 \%$ had more than one year of experience with Internet banking and about $33 \%$ had less than one year of experience.

We conducted a principal component factor analysis with Varimax rotation. The KMO measure of sampling adequacy value for the item was 0.871 , which was more than the recommended minimum of $0.6^{35}$. In addition, the Bartlett's Test of Sphericity was also significant (Chi square $=$ 1100.756, $p<0.001$ ). Trust, customer satisfaction, sense of belonging, and customer e-loyalty loaded well on their factors and explained $76.46 \%$ of the variance. The internal consistency method was employed using Cronbach's alpha and the Cronbach's alpha values for the components ranged from 0.762 to 0.810 . The Chronbach's alpha values indicated the reliability of the measurement used in this study.

Having confirmed the construct validity and instrument reliability, we ran a multiple regressions analysis. Table 1 summarizes the regressions results. 
Table 1. Regressions result

\begin{tabular}{llll}
\hline & DF & Sum of squares & Mean square \\
\hline Regression & 3 & 23.792 & 7.931 \\
Residual & 115 & 30.415 & .264 \\
\hline Variable & Beta & $\mathrm{t}$ & $\mathrm{VIF}$ \\
\hline Trust & $.290^{*}$ & 3.191 & 1.689 \\
Customer Satisfaction & $.295^{*}$ & 3.083 & 1.877 \\
Sense of Belonging & $.205^{*}$ & 2.427 & 1.462 \\
\hline Multiple R $=.663 ; \quad \mathrm{R}$ square $=.439 ;$ & Adjusted R square $=.424$ \\
Standard error= .51427 & & \\
\hline Note: * significant at $p<0.05 ; * * *$ significant at $p<0.001 ; \mathrm{N}=119$
\end{tabular}

As shown in Table 1, the $\mathrm{F}$ statistic for the final model indicated a significant model. The regression results also showed that trust $(\beta=.29, p$ $<.05)$, customer satisfaction $(\beta=.295, p<.05)$, and sense of belonging $(\beta$ $=.205, p<.05)$ on customer e-loyalty was statistically significant, which supported the three hypotheses in this study. Overall, trust, customer satisfaction, and sense of belonging together explained $43.9 \%$ of the variance in customer e-loyalty.

\section{DISCUSSION AND CONCLUSION}

The results of this study support that customer e-loyalty is directly affected by satisfaction, trust, and sense of belonging. Consistent with findings in the other empirical studies ${ }^{6,15,22}$, this study also indicated the importance of both trust and customer satisfaction in influencing customer e-loyalty of Internet banking. As sense of belonging has not been widely tested in the field, we elaborates a bit on the practical implications of this study's findings related to this construct. Specifically, sense of belonging is an important factor for predicting customer e-loyalty and is consistent with findings of similar previous studies, such as Kim et al. ${ }^{30}$. From a managerial perspective, Internet banking providers should enhance individual customer's sense of belonging to Internet banking. Several mechanisms can help users identify themselves as members of that particular bank. For example, Internet banking providers can give members more privileges, such as highly secure e-mail, compared to non-members, so as to give the members a feeling of being more valuable to the bank.

There are some limitations to this research as with any study. The research was conducted on college students from a public university in Malaysia. Therefore, the study might not reflect customer's e-loyalty toward Internet banking services in a larger population. Another limitation might be the fact that other factors need to be tested to show their influence on 
customer e-loyalty. Thus, future research could extend the study by testing other factors, such as electronic word of mouth and e-branding.

\section{REFERENCES}

[1] Ainin Sulaiman, C.H. Lim, and A. Wee, Prospect and challenges of e-banking in Malaysia. The Electronic Journal on Information System in Developing Countries, 22(1), p1-11, 2005.

[2] J. Thornton, and L. White, Customer orientations and usage of financial distribution channels. Journal of Services Marketing, 15(3), p168-185, 2001. doi:10.1108/08876040110392461.

[3] T. Pikkarainen, K. Pikkarainen, and H. Karjaluoto, Consumer acceptance of online banking: An extension of the technology acceptance model. Internet Research, 14(3), p224-235, 2004. doi:10.1108/10662240410542652.

[4] F.F. Reichheld, R.G. Markey, and C. Hopton, E-customer loyalty -Applying the traditional rules of business for online success. European Business Journal, 12(4), p173-179, 2000.

[5] F.F. Reichheld, and P. Schefter, E-loyalty: your secret weapon on the web. Harvard Business Review, 78(4), p105-113, 2000.

[6] D. Ribbink, A.C.R. Van Riel, and V. Liljander, Comfort your online customer: Quality, trust and loyalty on the internet. Managing Service Quality, 14(6), p446-456, 2004. doi:10.1108/09604520410569784.

[7] C. Sohn, and D. Lee, Trust and switching cost as a way to build e-loyalty in internet markets. International Journal of Internet and Enterprise Management, 2(3), p209- 220, 2004.

[8] S.S. Srinivasan, R.E. Anderson, and K. Ponnavolu, Customer loyalty in e-commerce: An exploration of its antecedents and consequences. Journal of Retailing, 78(1), p41-51, 2002. doi:10.1016/S0022-4359(01)00065-3.

[9] M. Gommans, K.S. Krishnan, and K.B. Scheffold, From brand loyalty to e-loyalty: A conceptual framework. Journal of Economic and Social Research, 3(1), p43-58, 2001.

[10] B. Lewis, and M. Soureli, The antecedents of consumer loyalty in retail banking. Journal of Consumer Behaviour, 5(1), p15-31, 2006. doi:10.1002/cb.46.

[11] C. Moorman, R. Desphandé, and G. Zaltman, Factors affecting trust in market research relationships. Journal of Marketing, 57(1), p81-101, 1993. doi:10.2307/1252059.

[12] R. Amit, and C. Zott, Value creation in e-business. Strategic Management Journal, 22 (6/7), p493-520, 2001. doi:10.1002/smj.187.

[13] H. McKnight, V. Choudhury, and C. Kacmar, Developing and validating trust measures for e-commerce: An integrative typology. 
Information Systems Research, 13(3), p334-359, 2002. doi:10.1287/isre.13.3.334.81.

[14] S. Chow, Toward an understanding of loyalty: the moderating role of trust. Journal of Managerial Issues, 9(3), p275-298, 1997.

[15] A. Floh, and H. Treiblmaier, What keeps the e-banking customer loyal? A multigroup analysis of the moderating role of consumer characteristics on e-loyalty in the financial service industry. Journal of Electronic Commerce Research, 7(2), p97-110, 2006.

[16] J. Gummerus, V. Liljander, M. Pura, and A. Van Riel, Customer loyalty to content-based Web sites: The case of an online health care service. Journal of Services Marketing, 18(3), p175-186, 2004. doi:10.1108/08876040410536486.

[17] Y. Cho, I. Im, R. Hiltz, and J. Fjermestad, The effects of post-purchase evaluation factors on online vs offline customer complaining behavior: Implications for customer loyalty. Advances in Consumer Research, 29(1), p318-326, 2002.

[18] A. Beerli, J.D. Martin, and A. Quintana, A model of customer loyalty in the retail banking market. European Journal of Marketing, 38(1/2), p253-275, 2004. doi:10.1108/03090560410511221.

[19] A. Martensen, L. Grønholdt, and K. Kristensen, The drivers of customer satisfaction and loyalty: Cross-industry findings from Denmark. Total Quality Management, 11(4/5/6), p544-553, 2000. doi:10.1080/09544120050007878.

[20] L.A. Crosby, and N. Stephens, Effects of relationship marketing on satisfaction, retention, and prices in the life insurance industry. Journal of Marketing Research, 24(4), p404-411, 1987. doi:10.2307/3151388.

[21] R.N. Bolton, A dynamic model of the duration of the customer's relationship with a continuous service provider: The role of satisfaction. Marketing Science, 17(1), p45-65, 1998. doi:10.1287/mksc.17.1.45.

[22] C. Flavián, M. Guinaliu, and R. Gurrea, The role played by perceived usability, satisfaction and consumer trust on Website loyalty. Information \& Management, 43(1), p1-14, 2006. doi:10.1016/j.im.2005.01.002.

[23] P. Luarn, and H.H. Lin, A customer loyalty model for e-service context. Journal of Electronic Commerce Research, 4(4), p156-167, 2003.

[24] D. Cyr, K. Hassanein, M. Head, and A. Ivanov, The role of social presence in establishing loyalty in e-service environments. Interacting with Computers, 19(1), p43-56, 2007. doi:10.1016/j.intcom.2006.07.010.

[25] R.L. Oliver, Whence consumer loyalty? Journal of Marketing, 63, p33-44, 1999. doi:10.2307/1252099.

[26] R.M. Morgan, and S.D. Hunt, The commitment-trust theory of relationship marketing. Journal of Marketing, 58(3), p20-39, 1994. 
doi: $10.2307 / 1252308$.

[27] J. Hagel III, and A. Armstrong, Net Gain: Expanding Markets through Virtua Communities. Boston, MA: Harvard Business School Press, 1997.

[28] T.L. Roberts, Are newsgroups virtual communities. Paper presented at SIGCHI Conference on Human Factors in Computing Systems, Los Angeles, CA USA, April 18-23, 1998. doi:10.1145/274644.274694.

[29] L.U. Juan, and L.U. Yan, Dimensions and influencing factors of customer loyalty in the intermittent service industry. Frontiers of Business Research in China, 3(1), p63-78, 2009.

[30] W.G. Kim, C. Lee, and S.J. Hiemstra, Effects of an online virtual community on customer loyalty and travel product purchases. Tourism Management, 25(2), p343-355, 2004. doi:10.1016/S0261-5177(03)00142-0.

[31] F.R. Dwyer, P.H. Schurr, and S. On, Developing buyer and seller relationships. Journal of Marketing, 51(2), p11-27, 1987. doi:10.2307/1251126.

[32] K. Md. Nor, and J.M. Pearson, An exploratory study into the adoption of Internet banking in a developing country: Malaysia. Journal of Internet Commerce, 7(1), p29-73, 2008. doi:10.1080/15332860802004162.

[33] Yuan-shuh Lii, A model of customer e-loyalty in the online banking. Economics Bulletin, 29(2), p892-903, 2009.

[34] K.A. Bollen, and R.H. Hoyle, Perceived cohesion: A conceptual and empirical examination. Social Forces, 69(2), p479-504, 1990. doi: $10.2307 / 2579670$.

[35] H. Kaiser, An index of factorial simplicity. Psychometrika, 39(1), p31-36, 1974. doi:10.1007/BF02291575. 